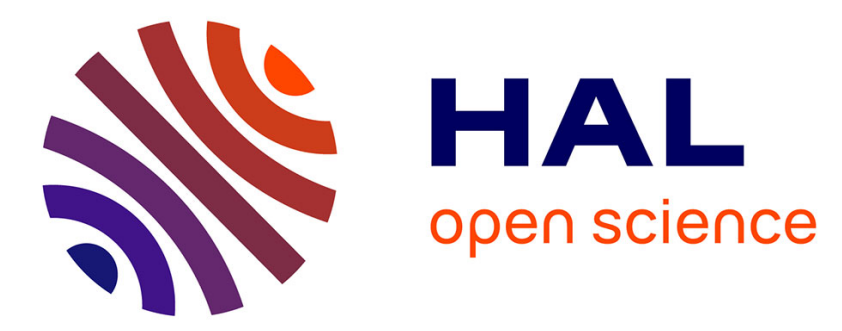

\title{
Study about the kinetic processes of biomass steam gasification
}

Capucine Dupont, Guillaume Boissonnet, Jean-Marie Seiler, Paola Gauthier, Daniel Schweich

\section{To cite this version:}

Capucine Dupont, Guillaume Boissonnet, Jean-Marie Seiler, Paola Gauthier, Daniel Schweich. Study about the kinetic processes of biomass steam gasification. Fuel, 2006, 86 (1-2), pp.32-40. 10.1016/j.fuel.2006.06.011 . cea-02356025

\section{HAL Id: cea-02356025 https://hal-cea.archives-ouvertes.fr/cea-02356025}

Submitted on 9 Dec 2019

HAL is a multi-disciplinary open access archive for the deposit and dissemination of scientific research documents, whether they are published or not. The documents may come from teaching and research institutions in France or abroad, or from public or private research centers.
L'archive ouverte pluridisciplinaire HAL, est destinée au dépôt et à la diffusion de documents scientifiques de niveau recherche, publiés ou non, émanant des établissements d'enseignement et de recherche français ou étrangers, des laboratoires publics ou privés. 


\title{
Study about the kinetic processes of biomass steam gasification
}

\author{
Capucine Dupont ${ }^{\mathrm{a}, *}$, Guillaume Boissonnet ${ }^{\mathrm{a}}$, Jean-Marie Seiler ${ }^{\mathrm{a}}$, \\ Paola Gauthier ${ }^{\mathrm{a}}$, Daniel Schweich ${ }^{\mathrm{b}}$ \\ ${ }^{a}$ Commissariat à l'Energie Atomique (CEA) Grenoble, DTN/SE2T/LPTM, 17 rue des Martyrs, 38054 Grenoble Cedex 09, France \\ ${ }^{\mathrm{b}}$ LGPC, CNRS-ESCPE, 43 bd du 11 Novembre, BP 2077, 69616 Villeurbanne Cedex, France
}

Received 3 May 2006; received in revised form 9 June 2006; accepted 13 June 2006

Available online 21 July 2006

\begin{abstract}
Modelling approaches of biomass steam gasification are investigated that take into account both chemical and physical kinetic limitations. The gas phase can be described by two independent reactions: (i) the steam reforming of $\mathrm{CH}_{4}$, which is kinetically limited under the operating conditions $(1073<T<1273 \mathrm{~K}, p=1 \mathrm{bar})$, (ii) the water-gas shift reaction, which would be close to equilibrium under the operating conditions $(1073<T<1273 \mathrm{~K}, p=1$ bar). Concerning solid, a time scale analysis of the main phenomena has been performed. For particles of $500 \mu \mathrm{m}$, the transformation can be seen as two successive steps: (i) pyrolysis of biomass, which is both chemically and heat-transfer controlled; (ii) steam gasification of residue, which is chemically controlled.
\end{abstract}

(C) 2006 Elsevier Ltd. All rights reserved.

Keywords: Biomass; Gasification; Modelling

\section{Introduction}

Modelling of biomass steam gasification to synthesis gas is a challenge because of the variability (composition, structure, reactivity, physical properties, etc.) of the raw material and because of the severe conditions (temperature, residence time, heating rate, etc.) required. This is well-illustrated in a fluidized gasification system as shown in Table 1.

This study proposes a modelling approach of biomass steam gasification, which aims at reconciling two opposing goals:

- The fundamental goal consists in understanding the mechanisms of the transformation. The model has to be physically meaningful.

- The applied goal requires a model able to predict the efficiency of the process and the effect of the main operating variables. The model has to be as simple as possible although reliable.

\footnotetext{
* Corresponding author. Tel.: +3343878 30 62; fax: +33438785251. E-mail address: capucine_dupont@hotmail.fr (C. Dupont).
}

The model should be able to predict the following characteristics:

- Total gas yield.

- Gas composition $\left(\mathrm{H}_{2}, \mathrm{CO}, \mathrm{CO}_{2}, \mathrm{CH}_{4}\right.$ and $\left.\mathrm{H}_{2} \mathrm{O}\right)$.

- Yield of solid residue.

Section 2 is a critical review of some interesting approaches found in the literature. Based on this background, kinetic modelling is investigated in Section 3. In Section 3.1, a description of the gas phase is proposed that is based on the kinetic study of the independent reactions of the system. The solid phase is studied through a characteristic time analysis of the main phenomena in Section 3.2. Eventually, conclusions are drawn in Section 4.

\section{Background}

Since attention was paid to modelling studies of thermochemical conversion of biomass during the seventies, different modelling approaches have been used. Two of them can be of interest for our study. 


\section{Nomenclature}

$B i_{\mathrm{M}} \quad$ material Biot number (ratio between the characteristic time of internal mass diffusion and of external mass transfer)

$B i_{\mathrm{T}} \quad$ thermal Biot number (ratio between the characteristic time of internal heat conduction and of external heat transfer by convection)

$c_{p} \quad$ heat capacity $\left(\mathrm{J} \mathrm{kg}^{-1} \mathrm{~K}^{-1}\right)$

$d_{\mathrm{p}} \quad$ diameter of particle $(\mathrm{m})$

$D_{\mathrm{m}} \quad$ gas mass diffusivity $\left(\mathrm{m}^{2} \mathrm{~s}^{-1}\right)$

$f \quad$ fraction of unconverted solid

$g \quad$ gravitational acceleration $\left(\mathrm{m}^{2} \mathrm{~s}^{-1}\right)$

$h_{\mathrm{m}} \quad$ coefficient of external mass transfer $\left(\mathrm{m} \mathrm{s}^{-1}\right)$

$h_{\mathrm{T}} \quad$ coefficient of external heat transfer by convection $\left(\mathrm{W} \mathrm{m}^{-2} \mathrm{~K}^{-1}\right)$

$k_{i} \quad$ kinetic constant of reaction $i$ (variable)

$K_{\text {shift eq }}$ equilibrium constant of water-gas shift

$K_{\text {shift exp }}$ reaction constant of water-gas shift

$m$ factor associated with the shape of the particle

$M_{i} \quad$ molecular weight of species $i\left(\mathrm{~kg} \mathrm{~mol}^{-1}\right)$

$n \quad$ stoichiometric coefficient of $\mathrm{H}_{2} \mathrm{O}$ (Eq. (2))

$p \quad$ pressure $(\mathrm{Pa})$

$P_{i \exp } \quad$ experimental partial pressure of species $i(\mathrm{~Pa})$

Py pyrolysis number (ratio between the characteristic time of biomass pyrolysis reaction and of internal heat conduction)
$\begin{array}{ll}R e_{\mathrm{P}} & \text { Reynolds related to particle } \\ S / B & \text { steam/dry biomass }(\mathrm{kg} / \mathrm{kg}) \\ t_{i} & \text { characteristic time }(\mathrm{s}) \\ T & \text { temperature }(\mathrm{K}) \\ v_{\mathrm{t}} & \text { free settling velocity }\left(\mathrm{m} \mathrm{s}^{-1}\right)\end{array}$

Greek letters

$\beta \quad$ stoichiometric coefficient

$\delta \quad$ diameter of pores $(\mathrm{m})$

$\lambda \quad$ thermal conductivity $\left(\mathrm{W} \mathrm{m}^{-1} \mathrm{~K}^{-1}\right.$ )

$\mu \quad$ dynamic viscosity (Pa s)

$\rho \quad$ density $\left(\mathrm{kg} \mathrm{m}^{-3}\right)$

$\sigma \quad$ Boltzmann constant $\left(\mathrm{W} \mathrm{m}^{-2} \mathrm{~K}^{-4}\right)$

$\omega$ emissivity

\section{Subscripts and superscripts}

g gas

$\mathrm{p}$ particle

Other symbol

$\%$ wdaf mass percent dry ash free
Table 1

Biomass and process characteristics

\begin{tabular}{ll}
\hline Input data & Range of values (estimated from $[3,29]$ ) \\
\hline $\mathrm{C}, \mathrm{H}, \mathrm{O}$ amount & Biomass composition \\
& $\mathrm{C}: 51 \%$ wdaf \\
$\mathrm{H}: 6 \%$ wdaf \\
$\mathrm{O}: 43 \%$ wdaf \\
S $/ B^{\mathrm{a}}:$ from 0.3 to $1 \mathrm{~kg} / \mathrm{kg}$ \\
Biomass particle size & Up to $1-2 \mathrm{~mm}$ \\
Temperature & $1073-1273 \mathrm{~K}$ \\
Pressure & Atmospheric \\
Heating rate & Flash $\left(>500^{\circ} \mathrm{C} \mathrm{s}^{-1}\right)$ \\
Gas residence time & $0.1-10 \mathrm{~s}$ \\
\hline
\end{tabular}

a $\left(\frac{S}{B}\right)=\frac{\text { steam }}{\text { dry biomass }}=\frac{m_{\mathrm{H}_{2} \mathrm{Ogas}}+m_{\mathrm{H}_{2} \mathrm{O}_{\text {liquid }}}}{\mathrm{m}_{\mathrm{dry}} \text { biomass }}$.

\subsection{Thermodynamic approach and "improved thermodynamic" approach}

One approach is focused on thermodynamic equilibrium. The input data are the amount of elements $\mathrm{C}, \mathrm{H}, \mathrm{O}$ in the system, temperature and pressure. A solver minimizes the Gibbs energy of the closed system to give the composition of the mixture. This tool relies on thermodynamic databases that contain the values of the standard Gibbs energy of the components. Most gaseous components can be found in such data bases, but concerning solid phase, only pure carbon is taken into account. Such a model does not require any knowledge of the mechanisms of transformation. Moreover, it is independent of the reactor and not limited to a specified range of operating conditions.

$\mathrm{Li}$ et al. [1] applied this approach to air gasification of biomass in a circulating fluidised bed. Comparisons were made in [2-5] between the predictions of the equilibrium model applied to steam gasification and experimental results from Hofbauer et al. [6] and Rapagna et al. [7]. It can be seen that the model gives correct orders of magnitude and trends. However, the equilibrium model always overestimates the yield of $\mathrm{H}_{2}$ and $\mathrm{CO}$ whereas it underestimates the yield of $\mathrm{CO}_{2}$. It predicts a gas nearly free of $\mathrm{CH}_{4}$, free of tars-modelled as $\mathrm{C}_{10} \mathrm{H}_{8}$ - and no solid residue. Thus, this type of model does not seem to be accurate enough for designing purpose of gasifiers.

To our knowledge, improvements of these models have been examined only in the case of air gasification. Kersten et al. [8] have developed a quasi-equilibrium temperature (QET) model based on equilibrium calculations made at a temperature lower than the reactor temperature. Kersten et al. [8] and Li et al. [1] have added empirical relations to their initial thermodynamic models to calculate the carbon conversion and the yield of $\mathrm{CH}_{4}$. The use of these correlations is limited to the reactors under study. The "QET" or correlation-based models are empirical and dead-end approaches restricted to the studied systems. 


\subsection{Phenomenological models based on kinetics}

\subsubsection{Models at particle scale}

Very sophisticated models have been derived at particle scale. They are focused only on one of the two main stages of steam gasification of biomass:

- either pyrolysis, that is the decomposition of the initial solid into permanent gases, condensable gases often called tars and a solid residue often called char;

- or gasification, that is the reaction of the solid residue with reactive gases such as steam.

The first of these models was probably published by Bamford et al. [9]. They are based on mass and energy balances over the particle, and the boundary conditions associated. The differences are found in the hypotheses of the models, mainly concerning:

- the description of the physical properties of the solid during the transformation. Their evolution with time or conversion is sometimes taken into account, which dramatically increases the number of adjustable parameters of the model [10];

- the phenomena that are taken into account. A historical survey shows that a significant effort has been made on the description of the different transport phenomena but all these models describe the complex chemical phenomena very roughly. The chemical phenomena are indeed still poorly understood. Contrary to the physical phenomena, there is no universal law to describe rates of reaction and the nature of the chemical pathways is believed to vary with the operating conditions, especially with the heating rate. More or less complex kinetic schemes are proposed. The effort on the description of the chemical pathways increases the number of parameters which must be determined. However, the reliability, the confidence intervals and the consistency of the parameters is rarely discussed.

For the description of the pyrolysis chemistry, semiglobal mechanisms are proposed, such as the description of Shafizadeh for cellulose [11] which is given in Eq. (1). These descriptions are interesting since they seem to be a first step towards the understanding of the complex pyrolysis chemistry. Nevertheless, the composition of the gases cannot be predicted by this model because the amount of $\mathrm{C}, \mathrm{H}$ and $\mathrm{O}$ in the initial solid are not input data of the model. The material is considered as a single species, such as biomass or wood, or as a mixture of species [12] but it is never referred to its elemental composition of $\mathrm{C}, \mathrm{H}$ and $\mathrm{O}$.

$$
\text { cellulose } \stackrel{k_{1}}{\rightarrow} \text { active cellulose } \stackrel{k_{3}}{\rightarrow} 0.35 \text { char }+0.65 \text { gas }
$$

Concerning the chemistry of steam gasification of biomass residue, most authors assume that the solid residue is pure carbon. Kinetic laws obtained on coal or pure carbon are then used $[13,14]$. As already told for pyrolysis reactions, using kinetic laws implies that kinetic parameters are added to the physical parameters to be determined. Note that Di Blasi [15] roughly accounts for the true nature of biomass by considering the amount of $\mathrm{H}$ and $\mathrm{O}$ in the residue. Matsui et al. [16] compiled the heterogeneous reaction of carbon with steam and the homogeneous reaction of water-gas shift into a single reaction, with a stoichiometric coefficient $(1+\beta)$ associated to $\mathrm{H}_{2} \mathrm{O}$. From a thermodynamic or kinetic viewpoint, lumping together two independent reactions is hazardous, especially when one of these reactions, namely water-gas shift, is welldocumented.

\subsubsection{Characteristic time analysis}

Some authors have developed a rational approach of simplification of the kinetic models. A comparison is made between the time scales of the different phenomena involved in the reaction.

Some authors directly compare the characteristic times of the phenomena. Chan et al. [10] made this work in the case of wood pyrolysis both at the scale of particle and at the scale of the particle pores for $1 \mathrm{~cm}$-particles. It was concluded that chemical reaction was limiting at $500 \mathrm{~K}$ whereas internal heat conduction was limiting at $1100 \mathrm{~K}$. Van de Steene [17] applied this method to coal combustion in order to find the best experimental conditions to minimize the coupling between phenomena. Russel et al. [18] used the time scales analysis to derive a simplified model of coal hydropyrolysis.

The comparison is often made in terms of characteristic time ratios to point the limiting phenomena. As initially proposed by Damköhler [19], dimensionless numbers can be defined with these ratios. According to their order of magnitude, different regimes can be determined. However, this method of comparison hides the absolute time scales of the phenomena. This approach was first applied to the devolatilisation of a solid by Villermaux and Antoine [20]. His aim was to predict the conversion time of a particle. Two regimes of devolatilisation were defined, depending on the ratio between the characteristic time of the chemical reaction and of the internal heat conduction process.

Pyle and Zaror [21] accounted for external heat transfer limitations. Experimental data were used to validate the simplified models for different particle sizes under slow pyrolysis conditions. Bryden et al. [22] considered the case in which internal and external heat transfer processes were both limiting.

In order to show which particle size could be used for an intrinsic kinetic study of biomass pyrolysis, Simmons and Gentry [23] plotted the limit between thermal and chemical regimes as a function of temperature and particle size. According to his calculations, at $773 \mathrm{~K}$, particles smaller than $100 \mu \mathrm{m}$ are required to be under chemical control but according to his flash pyrolysis experiments, this size 
is reduced to $10 \mu \mathrm{m}$. Wutti et al. [24] used the results of his model to draw similar graphs. The relative influence of the different heat transfer phenomena on the transformation was shown for different gas velocities. More recently, Peters and Bruch [25] plotted the ratio of the characteristic time of the chemical reaction to the internal heat conduction time versus particle diameter for different temperatures up to $873 \mathrm{~K}$. At this temperature, the transition zone between the chemical and thermal regimes was found to be between 50 and $500 \mu \mathrm{m}$. Note that the limits found by Peters and Simmons are not in agreement. This may be due to the large discrepancies in the data used for the study and to the different operating conditions, namely heating rate.

The characteristic times analysis is an efficient way to derive simplified models that keep a physical significance. Nevertheless, such simplified models lose some part of generality since they are restricted to the range of operating conditions under which the simplifications are valid.

It is worth noting that time scales analysis has been mainly used in the case of pyrolysis. No similar study could have been found concerning biomass steam gasification.

\section{Kinetic modelling}

The global chemistry can be described by Eq. (2).

$\mathrm{C}_{x} \mathrm{H}_{y} \mathrm{O}_{z}+n \mathrm{H}_{2} \mathrm{O} \stackrel{T}{\rightarrow} \mathrm{C}_{x^{\prime}} \mathrm{H}_{y^{\prime}} \mathrm{O}_{z^{\prime}}+$ gases

An initial solid of known formula $\mathrm{C}_{x} \mathrm{H}_{y} \mathrm{O}_{z}$ reacts under heat and steam to give two kinds of products:

- A solid residue of generic formula $\mathrm{C}_{x^{\prime}} \mathrm{H}_{y^{\prime}} \mathrm{O}_{z^{\prime}}$.

- Gases.

\subsection{Gas phase description}

Equilibrium calculations based on the amount of $\mathrm{C}, \mathrm{H}$ and $\mathrm{O}$ contained in the gas phase of some experiments $[6,7]$, were made in order to check whether the gas phase was at thermodynamic equilibrium. As shown in Table 2, under these conditions $(1073<T<1273 \mathrm{~K}, p=1$ bar $)$, the gas phase composition at equilibrium is clearly different from the experimental composition. The experimental gas composition shows $25 \%$ less $\mathrm{H}_{2}$, about $20 \%$ less $\mathrm{CO}$, about $20 \%$ more $\mathrm{H}_{2} \mathrm{O}$ and a significant yield of $\mathrm{CH}_{4}$, whereas nearly no $\mathrm{CH}_{4}$ is predicted at equilibrium. These results prove that gas phase is not at equilibrium.

The gas phase is assumed to be a system made up of the five main species observed in experiments: $\mathrm{H}_{2}, \mathrm{CO}, \mathrm{CO}_{2}$, $\mathrm{CH}_{4}, \mathrm{H}_{2} \mathrm{O}$. As explained in [26], this reacting system can be fully described by two independent reactions:

- The water-gas shift reaction:

$$
\mathrm{CO}+\mathrm{H}_{2} \mathrm{O} \rightleftharpoons \mathrm{CO}_{2}+\mathrm{H}_{2}
$$

Table 2

Gas phase composition given by experiments and by equilibrium calculations on gas phase

\begin{tabular}{llll}
\hline $\begin{array}{l}\text { mol/mol dry } \\
\text { biomass input }\end{array}$ & $\begin{array}{l}\text { (a) Experimental } \\
\text { results [7] }\end{array}$ & $\begin{array}{l}\text { (b) Gas phase at } \\
\text { thermodynamic } \\
\text { equilibrium }\end{array}$ & (a) $-($ b) \\
\hline $\mathrm{H}_{2}$ & 5.34 & 7.19 & -1.85 \\
$\mathrm{CO}$ & 3.55 & 4.40 & -0.85 \\
$\mathrm{CO}_{2}$ & 1.64 & 1.46 & 0.17 \\
$\mathrm{CH}_{4}$ & 0.69 & 0.01 & 0.67 \\
$\mathrm{H}_{2} \mathrm{O}$ & 2.86 & 2.36 & 0.5 \\
\hline
\end{tabular}

Almond shells $\mathrm{C}_{6} \mathrm{H}_{8.6} \mathrm{O}_{3.7} ; T=1093 \mathrm{~K} ; p=1$ bar; steam/dry biomass $=$ $0.63 \mathrm{~kg} / \mathrm{kg}$; olivine.

- The steam reforming of $\mathrm{CH}_{4}$ :

$$
\mathrm{CH}_{4}+\mathrm{H}_{2} \mathrm{O} \rightleftharpoons \mathrm{CO}+3 \mathrm{H}_{2}
$$

The objective of this section is to detect which of homogeneous gas phase reactions are at thermodynamic equilibrium and which are kinetically limited.

The homogeneous gas phase steam reforming of $\mathrm{CH}_{4}$ was studied using Chemkin software [27]. The objective was to compare the time evolution of the gas composition obtained under operating conditions of interest $[6,28]$ with equilibrium predictions. The results are given in Table 3 . In Hofbauer's experiments, the five main species $\left(\mathrm{H}_{2}, \mathrm{CO}\right.$, $\mathrm{CO}_{2}, \mathrm{CH}_{4}$ and $\mathrm{H}_{2} \mathrm{O}$ ) are considered only. The calculated composition is nearly constant from 100 to $1000 \mathrm{~s}$ and significantly different from the equilibrium composition. In Déglise's experiments, the hydrocarbons with two carbon atoms are considered. The evolution of the gaseous mixture toward equilibrium is favoured by the presence of $\mathrm{C}_{2}$ hydrocarbons but thermodynamic equilibrium is far from being reached at $10^{3} \mathrm{~s}$. From a modelling viewpoint, it can be concluded that the steam reforming of $\mathrm{CH}_{4}$ is kinetically limited.

Rapagna et al. [7] have calculated the reaction constant of water-gas shift, which is defined by Eq. (5), with the experimental partial pressures. For comparison, the

Table 3

Simulation of the evolution of the experimental gas phase composition

\begin{tabular}{|c|c|c|c|c|c|}
\hline & $\begin{array}{l}\text { Gas } \\
\text { composition } \\
(\mathrm{mol} \%)\end{array}$ & $\begin{array}{l}t=0 \mathrm{~s} \\
\text { (experimental } \\
\text { data) }\end{array}$ & $10^{2} \mathrm{~s}$ & $10^{3} \mathrm{~s}$ & Equilibrium \\
\hline $\begin{array}{l}\text { Hofbauer's } \\
\text { data [6], } \\
\begin{array}{l}T=1093 \mathrm{~K}, \\
p=1 \text { bar }\end{array}\end{array}$ & $\begin{array}{l}\mathrm{H}_{2} \\
\mathrm{CO} \\
\mathrm{CO}_{2} \\
\mathrm{CH}_{4} \\
\mathrm{H}_{2} \mathrm{O}\end{array}$ & $\begin{array}{c}33.2 \\
15.6 \\
14.4 \\
4.40 \\
32.4\end{array}$ & $\begin{array}{c}33.2 \\
15.6 \\
14.4 \\
4.40 \\
32.4\end{array}$ & $\begin{array}{c}33.4 \\
15.4 \\
14.6 \\
4.39 \\
32.2\end{array}$ & $\begin{array}{c}42.0 \\
19.0 \\
12.6 \\
0.02 \\
26.4\end{array}$ \\
\hline $\begin{array}{l}\text { Déglise's } \\
\text { data [28], } \\
\begin{array}{l}T=1073 \mathrm{~K} \\
p=1 \text { bar }\end{array}\end{array}$ & $\begin{array}{l}\mathrm{H}_{2} \\
\mathrm{CO} \\
\mathrm{CO}_{2} \\
\mathrm{CH}_{4} \\
\mathrm{H}_{2} \mathrm{O} \\
\mathrm{C}_{2} \mathrm{H}_{4} \\
\mathrm{C}_{2} \mathrm{H}_{6} \\
\mathrm{C}_{2} \mathrm{H}_{2}\end{array}$ & $\begin{array}{c}11.5 \\
25.7 \\
2.5 \\
7.4 \\
48.9 \\
3.4 \\
0.13 \\
0.5\end{array}$ & $\begin{array}{c}14.6 \\
24.0 \\
5.8 \\
10.1 \\
43.8 \\
1.51 \\
0.2 \\
0.09\end{array}$ & $\begin{array}{c}21.5 \\
17.7 \\
12.8 \\
12.4 \\
35.4 \\
0.09 \\
0.02 \\
0.004 \\
\end{array}$ & $\begin{array}{c}47.3 \\
24.0 \\
10.4 \\
0.09 \\
18.1 \\
\# 0 \\
\# 0 \\
\# 0 \\
\end{array}$ \\
\hline
\end{tabular}
versus time and gas phase composition at equilibrium 
equilibrium constant of the reaction has also been calculated at the same temperature. We have applied this approach to different series of experiments:

- Hofbauer et al. [6] and Rapagna et al. [7] tests consist of biomass steam gasification in fluidised beds.

- Zanzi's experiments consist of biomass flash pyrolysis in a free-fall reactor [29].

$K_{\text {shift exp }}=\frac{P_{\mathrm{CO}_{2} \exp } \times P_{\mathrm{H}_{2} \exp }}{P_{\mathrm{CO} \exp } \times P_{\mathrm{H}_{2} \mathrm{Oexp}}}$

The results of these calculations are given in Table 4. In Hofbauer and Rapagna's experiments, the experimental reaction constants are of the same order of magnitude as the equilibrium constants. Under these operating conditions $(1073<T<1273 \mathrm{~K}, p=1$ bar, $0.3<S / B<1.2 \mathrm{~kg} /$ $\mathrm{kg}$ ), the water-gas shift reaction would be close to equilibrium. In Zanzi's tests, at $1073 \mathrm{~K}$, a difference about one order of magnitude can be observed between the experimental constant and the equilibrium constant. At $1273 \mathrm{~K}$, equilibrium seems to be reached. Several reasons for this difference may be suggested:

- In Zanzi's experiments, the yield of $\mathrm{H}_{2} \mathrm{O}$ may be overestimated since it is calculated by the difference using the mass balance. The denominator in Eq. (5) is thus overestimated.

- In Hofbauer and Rapagna experiments, a Fe-containing catalyst is used, which may promote the water-gas shift reaction. The presence of a steam excess may also favour the water-gas shift reaction.

Finally, it can be concluded that the equilibrium seems to be reached for the water-gas shift reaction at $1273 \mathrm{~K}$ at a residence time about $1 \mathrm{~s}$. Between 1073 and $1273 \mathrm{~K}$, this statement would need to be confirmed since the two series of experiments are not in agreement. Note that several authors assert that water-gas shift is at equilibrium at $1073 \mathrm{~K}[30,31]$.

As a first approximation, the following assumptions can be made under the operating conditions of interest $(1073<$ $T<1273 \mathrm{~K}, p=1 \mathrm{bar}$ ) for the system made up of the five main gaseous species $\left(\mathrm{H}_{2}, \mathrm{CO}, \mathrm{CO}_{2}, \mathrm{CH}_{4}\right.$ and $\left.\mathrm{H}_{2} \mathrm{O}\right)$ :

- The water gas shift reaction is at equilibrium.

- The steam reforming of $\mathrm{CH}_{4}$ is kinetically limited.

The evolution of the gas phase produced during the solid decomposition can be fully described using:

- The equilibrium relationship for the water gas shift reaction.

- A mass balance equation for $\mathrm{CH}_{4}$ including a specific kinetic rate expression for steam reforming.

- The atomic balances on $\mathrm{C}, \mathrm{H}$ and $\mathrm{O}$.

The latter balances require knowing the distribution of $\mathrm{C}$, $\mathrm{H}$ and $\mathrm{O}$ among the gas and solid phases during the reaction.

\subsection{Solid phase description: time scales analysis}

\subsubsection{Data used in calculations}

Some thermodynamic and physical properties of gases and solids and some chemical kinetic constants are required to estimate the characteristic times of the phenomena. A special attention has been put on estimating the degree of relevance of these properties and constants.

\subsubsection{Physical properties.}

- Intrinsic gas properties are known with enough accuracy for our study and are taken from [32]. Two assumptions are made concerning gases:

Table 4

Experimental constant and equilibrium constant of water-gas shift reaction

\begin{tabular}{|c|c|c|c|c|c|c|}
\hline Name of experiment & UNIVAQ $1 \mathrm{~kW}$ & UNIVAQ $1 \mathrm{~kW}$ & FICFB $10 \mathrm{~kW}$ & FICFB $100 \mathrm{~kW}$ & Zanzi birch 2 & Zanzi birch 3 \\
\hline Source & [7] & [7] & [6] & [6] & [29] & [29] \\
\hline Experimental facility & Fluidised bed & Fluidised bed & Fluidised bed & Fluidised bed & Free-fall reactor & Free-fall reactor \\
\hline Type of biomass & $\begin{array}{l}\text { Almond shells } \\
\mathrm{C}_{6} \mathrm{H}_{8.6} \mathrm{O}_{3.7}\end{array}$ & $\begin{array}{l}\text { Almond shells } \\
\mathrm{C}_{6} \mathrm{H}_{8.6} \mathrm{O}_{3.7}\end{array}$ & Wood $\mathrm{C}_{6} \mathrm{H}_{8,8} \mathrm{O}_{3.6}$ & Wood $\mathrm{C}_{6} \mathrm{H}_{8.8} \mathrm{O}_{3.6}$ & Birch wood $\mathrm{C}_{6} \mathrm{H}_{8.3} \mathrm{O}_{4.2}$ & Birch wood $\mathrm{C}_{6} \mathrm{H}_{8.3} \mathrm{O}_{4.2}$ \\
\hline Particle size (mm) & 1.1 & 1.1 & Not given & Not given & $0.8-1$ & $0.8-1$ \\
\hline$T(\mathrm{~K})$ & 1043 & 1093 & 1123 & 1073 & 1073 & 1273 \\
\hline $\begin{array}{l}\text { Steam/dry biomass } \\
(\mathrm{kg} / \mathrm{kg})\end{array}$ & 1.2 & 1.2 & 0.3 & 0.5 & 0 & 0 \\
\hline Fluidising agent & Olivine & Olivine & Sand? & Olivine & Without catalyst & Without catalyst \\
\hline Gas residence time & Not given & Not given & Not given & Not given & About $3 \mathrm{~s}^{\mathrm{a}}$ & About $3 \mathrm{~s}^{\mathrm{a}}$ \\
\hline Solid residence time & Not given & Not given & Not given & Not given & About $1 \mathrm{~s}^{\mathrm{a}}$ & About $1 \mathrm{~s}^{\mathrm{a}}$ \\
\hline $\begin{array}{l}\text { Experimental } \\
\quad \text { constant } K_{\text {shift } \exp }(-)\end{array}$ & 0.6 & 0.9 & 0.9 & 0.7 & 0.1 & 0.7 \\
\hline $\begin{array}{l}\text { Equilibrium } \\
\text { constant } K_{\text {shift éq }}(-)\end{array}$ & 1.2 & 1.0 & 0.9 & 1.1 & 1.1 & 0.6 \\
\hline$K_{\text {shift exp }} / K_{\text {shift éq }}(-)$ & 0.5 & 0.9 & 0.9 & 0.6 & 0.1 & 1.2 \\
\hline
\end{tabular}

${ }^{a}$ Estimated. 
- The gas phase is assumed to be ideal.

- The gas phase is assumed to be mainly made of $\mathrm{N}_{2}$ and $\mathrm{H}_{2} \mathrm{O}$.

Note that for the estimation of the gas diffusivity used in the time scales of internal mass diffusion, only molecular diffusion is taken into account. This is because the ratio of the estimated diameter of pores of the solid to the gases mean free path, calculated according to the kinetic theory of gases, is much higher than 1 . The molecular diffusion coefficient is calculated for a binary mixture $\mathrm{H}_{2} \mathrm{O}-\mathrm{N}_{2}$ with the correlation of Fuller-Schettler-Giddings [33].

- External heat and mass transfer coefficients are obtained by Ranz-Marshall correlations. These correlations describe heat and mass transfer to a single or isolated particle [34]. In the particle Reynolds number, $R e_{\mathrm{P}}$, the particle slip velocity is assumed to be equal to the particle free settling velocity in Stokes regime $\left(R e_{\mathrm{P}} \ll 1\right)$ :

$$
v_{\mathrm{t}}=\frac{g d_{\mathrm{p}}^{2}\left(\rho_{\mathrm{p}}-\rho_{\mathrm{g}}\right)}{18 \mu_{\mathrm{g}}}
$$

- Biomass physical properties are highly variable with the raw material. For this study, the biomass is a mixture of common softwoods, Sylvester pine and spruce. Properties were directly measured on the available samples or taken from literature dealing with this kind of wood.

- Information about physical properties of the solid residue is quite scarce in the literature $[35,36]$.

The thermodynamic and physical properties of biomass and solid residue are shown in Table 5.

\subsubsection{Chemical kinetic rate expressions. An accurate} description of the chemical phenomena is a key issue. The choice of chemical kinetic laws is difficult because there are as many kinetic laws as kinetic studies. A large discrepancy can be observed between them and it is highly hazardous to extrapolate literature results obtained under different operating conditions (reactor, heating rate, temperature, biomass type, heating rate of pyrolysis for residue).

The problem is essentially due to the empirical nature of the so-called rate expressions and to the fuzzy definition of the rate. Most authors assume first-order rates with respect to biomass. However, literature specialized on noncatalytic gas-solid reactions shows that this situation is not frequent at all [20,39-42]. An example is given by the consumption of a shrinking particle in the chemical regime: the rate expressed as moles (or mass) per unit current volume of particle and per unit time is shown to be proportional to $f^{-1 / m}$, where $f$ is the fraction of unconverted solid and $m$ a positive number ranging from 1 to 3 according to the shape of the particle ([42] for instance). Published firstorder kinetic rate constants are in fact apparent parameters that lump the intrinsic chemical process together with other possible processes of physical nature. Thus, one must be very careful when using published results, and one can only assume that these values are lower bounds to the true rate or rate constant.

- Few kinetic studies on biomass flash pyrolysis at relatively high temperatures were published. Two authors $[43,44]$ propose kinetic constants that are not really in agreement with a ratio about 5. They are shown in Table 6. Since there is no clear reason to give more credit to one of them, we calculated the characteristic time of pyrolysis reaction with both values.

- The step of gasification of residue may involve gas-solid reactions with the three reactive gases: $\mathrm{H}_{2} \mathrm{O}, \mathrm{CO}_{2}$ and $\mathrm{H}_{2}$. As a first approximation, only reaction with $\mathrm{H}_{2} \mathrm{O}$ is considered here since $\mathrm{H}_{2} \mathrm{O}$ is in excess during steam gasification. Steam gasification characteristic times were calculated from two sources:

- A kinetic law obtained in a thermobalance on a slow pyrolysis residue of softwood [45] among the numerous ones found in the literature on biomass or coal.

- A kinetic law obtained in a fluidised bed on a flash pyrolysis residue [46].

Since the gasification process is slow, one may assume that the constant reflects intrinsic chemistry essentially. The kinetic constants are shown in Table 7. In this case, the two constants are of the same order of magnitude. Only calculations made with Kojima's law are used on subsequent graphs.

There is an unavoidable lack of accuracy concerning the solid properties and the chemical kinetic constants. This point has to be kept in mind when using the characteristic time analysis.

Table 5

Thermodynamic and physical properties of solids

\begin{tabular}{|c|c|c|c|c|c|c|}
\hline Solid property & Symbol & Unit & Biomass value & Source & Solid residue value & Source \\
\hline Solid heat capacity & $c_{p \mathrm{p}}$ & $\mathrm{J} \mathrm{kg}^{-1} \mathrm{~K}^{-1}$ & 1522 & {$[37]$} & 1075 & {$[35]$} \\
\hline Apparent particle density & $\rho_{p \mathrm{p}}$ & $\mathrm{kg} \mathrm{m}^{-3}$ & 300 & Estimated & 100 & Estimated \\
\hline Diameter of pores & $\delta_{\mathrm{p}}$ & $\mathrm{m}$ & $10^{-5}$ & Estimated & $10^{-5}$ & Estimated \\
\hline Emissivity & $\omega_{\mathrm{p}}$ & - & 0.9 & {$[38]$} & 0.9 & Estimated \\
\hline Thermal conductivity $^{\mathrm{a}}$ & $\lambda_{\mathrm{p}}$ & $\mathrm{W} \mathrm{m}{ }^{-1} \mathrm{~K}^{-1}$ & 0.11 & {$[37]$} & 0.06 & $\begin{array}{l}\text { Estimated (twice less } \\
\text { than wood [35]) }\end{array}$ \\
\hline
\end{tabular}

\footnotetext{
${ }^{a}$ Thermal conductivity is an anisotropic property (up to a factor of 2 can be observed between the two directions parallel and perpendicular to the fibres). An average value is taken.
} 
Table 6

Flash pyrolysis kinetic laws

\begin{tabular}{lll}
\hline Source & Brink [43] & Biagini [44] \\
\hline $\begin{array}{l}\text { Experimental } \\
\text { apparatus }\end{array}$ & Flow reactor & Wire mesh reactor \\
$\begin{array}{l}\text { Heating rate } \\
\text { Temperature }\end{array}$ & Not given & $1000 \mathrm{~K} \mathrm{~s}^{-1}$ \\
& $920-1144 \mathrm{~K}$ & Up to $1673 \mathrm{~K}$ \\
Pressure & 1 bar & (range not given) \\
$\begin{array}{l}\text { Type of biomass } \\
\text { Particle size }\end{array}$ & White fir & Olive residue \\
$\begin{array}{l}\text { Type of kinetic law } \\
\text { Kinetic constant }\end{array}$ & $<175 \mu \mathrm{m}$ & $<84 \mu \mathrm{m}$ \\
& First order & First order \\
& $k_{\text {pyro }}\left(\mathrm{s}^{-1}\right)=2.64$ & $k_{\text {pyro }}\left(\mathrm{s}^{-1}\right)=3.27$ \\
& $\times 10^{5} \exp \left(\frac{-105,000}{R T}\right)$ & $\times 10^{6} \exp \left(\frac{-113,900}{R T}\right)$ \\
\hline
\end{tabular}

Table 7

Steam gasification kinetic laws

\begin{tabular}{lll}
\hline Source & Nandi [45] & Kojima [46] \\
\hline $\begin{array}{l}\text { Experimental } \\
\text { apparatus }\end{array}$ & Thermobalance & Fluidised bed \\
$\begin{array}{l}\text { Temperature } \\
\text { Pressure }\end{array}$ & $877-1144 \mathrm{~K}$ & $1123-1223 \mathrm{~K}$ \\
Type of biomass & 22 bar & 1 bar \\
Particle size & Pine Jack & Wood \\
Pyrolysis treatment & $\begin{array}{l}1.2-1.7 \mathrm{~mm} \\
\text { Slow (in a tubular }\end{array}$ & About $1-2 \mathrm{~mm}$ \\
Type of kinetic law & Furnace $)$ & \\
Kinetic constant & $k_{\text {gasif }}\left(\mathrm{s}^{-1}\right)=1.7$ & $k_{\text {gasif }}\left(\mathrm{s}^{-1}\right)=$ \\
& $\times 10^{5} \exp \left(\frac{-170,250}{R T}\right)$ & $1773 P_{\mathrm{H}_{2} \mathrm{O}}^{0.41} \exp \left(\frac{-179,000}{R T}\right)$ \\
\hline
\end{tabular}

\subsubsection{Results}

The definition of the main characteristic times for spherical particles and their value for particles of $500 \mu \mathrm{m}$ diameter at 1073 and $1273 \mathrm{~K}$ is given in Table 8 .

The order of magnitude of the main ratios of the characteristic times is given in Table 9 at 1073 and $1273 \mathrm{~K}$ for three particle sizes between 50 and $1000 \mu \mathrm{m}$.

Table 8

Definition of the characteristic times of the main phenomena and values associated with particles of $500 \mu \mathrm{m}$ at 1073 and $1273 \mathrm{~K}$

\begin{tabular}{|c|c|c|c|}
\hline \multirow[t]{2}{*}{$\begin{array}{l}\text { Physical and chemical } \\
\text { phenomena }\end{array}$} & \multirow[t]{2}{*}{$\begin{array}{l}\text { Definition of the } \\
\text { characteristic times }\end{array}$} & \multicolumn{2}{|c|}{$\begin{array}{l}\text { Time for particles of } \\
500 \mu \mathrm{m}^{\mathrm{a}}(\mathrm{s})\end{array}$} \\
\hline & & $T=1073 \mathrm{~K}$ & $T=1273 \mathrm{~K}$ \\
\hline Pyrolysis of biomass & $t_{\text {pyro }}=\frac{1}{k_{\text {pyro }}}$ & $0.1-0.5$ & $0.01-0.1$ \\
\hline $\begin{array}{l}\text { Steam gasification } \\
\text { of residue }\end{array}$ & $t_{\text {gasif }}=\frac{1}{k_{\text {gasif }}}$ & 1000 & 50 \\
\hline $\begin{array}{l}\text { External heat transfer } \\
\text { by convection }\end{array}$ & $t_{\text {ext conv }}=\frac{\rho_{\mathrm{p}} \mathrm{c}_{\mathrm{p}} d_{\mathrm{p}}}{6 h_{\mathrm{t}}}$ & 0.09 & 0.09 \\
\hline $\begin{array}{l}\text { External heat transfer } \\
\text { by radiation }\end{array}$ & $\frac{t_{\text {ext rad }}={ }_{\rho_{\mathrm{p}}} \mathrm{c}_{p \mathrm{p}} d_{\mathrm{p}}}{6 \omega \sigma \times\left(T_{\mathrm{g}}+T_{\mathrm{p}}\right) \times\left(T_{\mathrm{g}}^{2}+T_{\mathrm{p}}^{2}\right)}$ & 0.5 & 0.3 \\
\hline $\begin{array}{l}\text { Internal heat } \\
\text { conduction }\end{array}$ & $t_{\text {int cond }}=\frac{\rho_{\mathrm{p}} \mathrm{c}_{\mathrm{pp}} \lambda_{\mathrm{p}}^{2}}{36 \lambda_{\mathrm{p}}}$ & 0.03 & 0.03 \\
\hline External mass transfer & $\begin{array}{l}t_{\text {ext mass }}= \\
\frac{\rho_{\mathrm{p}} R T_{\mathrm{g}} d_{\mathrm{p}}}{6 h^{2} P_{\mathrm{m}} M_{\mathrm{H}} 0}\end{array}$ & 0.04 & 0.04 \\
\hline $\begin{array}{l}\text { Internal diffusion } \\
\text { of mass }\end{array}$ & $t_{\text {int mass }}=\frac{d_{\mathrm{m}} \mathrm{H}_{2} \mathrm{O}^{2} \mathrm{~L} \mathrm{H}_{2} \mathrm{O}}{36 D_{\mathrm{m}}}$ & 0.0004 & 0.0003 \\
\hline
\end{tabular}

${ }^{\text {a }}$ Data used for calculations are listed in Tables 5-7.

\subsubsection{Analysis and discussion of the results}

Within the range of temperatures under study $(1073<$ $T<1273 \mathrm{~K}$ ), the characteristic time of pyrolysis reaction is below $1 \mathrm{~s}$, whereas for the steam gasification reaction it is higher than $1 \mathrm{~min}$, or even higher than $1 \mathrm{~h}$ at $1073 \mathrm{~K}$. Experimentally, only pyrolysis may occur under pneumatic transport conditions that imply residence times smaller than $10 \mathrm{~s}$. In a fluidised bed, since the solid residence time can be more than $1 \mathrm{~h}$, steam gasification may occur.

The ratio between the characteristic times of steam gasification of residue and the biomass pyrolysis is much higher than 1. Consequently, the transformation can be modelled as two successive steps:

- Pyrolysis of biomass.

- Steam gasification of solid residue.

The characteristic times of the mass transfer processes, either internal or external, are below $1 \mathrm{~s}$ due to the relatively small particle size.

The ratio of the characteristic times of the internal mass transfer to the external mass transfer, called mass Biot number, $B i_{\mathrm{M}}$, is much smaller than 1. External mass transfer is therefore more limiting than internal mass diffusion for particles between 50 and $1000 \mu \mathrm{m}$.

The ratio between the characteristic times of the steam gasification reaction and the external mass transfer of gases is much higher than 1 . The chemical reaction is therefore the limiting step. Since the characteristic times of chemical reactions vary with the temperature only, this implies that the rate of conversion at this stage of the process is mostly influenced by temperature, not by particle size. This also means for modelling that the gases have enough time to penetrate the whole particle before the reaction takes place. Steam gasification can be assumed to occur uniformly over the whole residue.

The characteristic times of all the heat transfer processes are $1 \mathrm{~s}$ or less.

External heat transfer from the gas to the particle may occur by radiation or convection. The ratio between the characteristic times of radiation and convection is much higher than 1 for particles of $50 \mu \mathrm{m}$. Under these conditions, radiation is quite less efficient than convection. It can therefore be assumed that radiation is negligible and that external heat transfer occurs mainly by convection. For bigger particles, the ratio between the time scales is only a little bit higher than 1 . Both phenomena have to be taken into account.

The ratio between the characteristic times of internal heat conduction and external heat transfer by convection, also called thermal Biot number $B i_{\mathrm{T}}$, is about 1 under the whole range of operating conditions. Both phenomena may be limiting for the transformation.

The competition between the heat transfer processes and the chemical reaction of pyrolysis can be evaluated through the pyrolysis number Py. This number is the ratio between 
Table 9

Characteristic time ratios at 1073 and $1273 \mathrm{~K}$ for different particle sizes ${ }^{\mathrm{a}}$

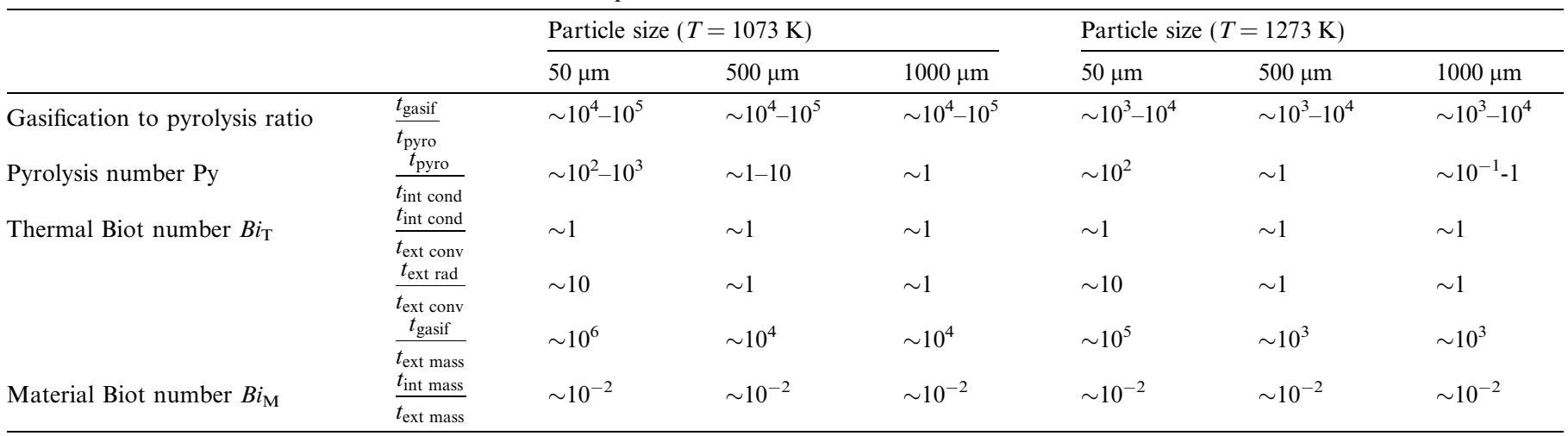

${ }^{\mathrm{a}}$ Data used for calculations are listed in Tables 5-7.

the characteristic time of the pyrolysis reaction and the internal conduction. As seen in Fig. 1, under the operating conditions of interest, its range of variation spreads from $10^{-1}$ to $10^{3}$, that is four orders of magnitude. Therefore, different regimes of pyrolysis have to be considered.

In Fig. 1, the limits between the regimes are plotted versus temperature and particle size. The limit above which chemical regime prevails is defined by $P y=10$, whereas the limit under which thermal regime prevails is defined by $P y=0.1$. Note that the limits are made of two thick hatched bands, which take into account the uncertainty on chemical kinetic data. Pyrolysis is limiting for particles smaller than $100 \mu \mathrm{m}$ up to $1100 \mathrm{~K}$. Heat transfer processes can be assumed to be instantaneous and the particle is considered as isothermal. This situation is well-adapted to chemical kinetic experiments. Under the other realistic operating conditions under study, the characteristic times associated with heat transfers and chemical reaction of pyrolysis are of the same order of magnitude. Neither of the process can be assumed to be limiting. This is the most complex situation, either for experiments or modelling, due to the coupling of the different phenomena. The particle transformation has to be described by a thick front of reaction moving towards the particle centre with time. Note that the thermal regime is reached only for particles bigger than $1 \mathrm{~cm}$.

A direct comparison of this graph with those previously published in the literature $[23,25]$ is difficult because the

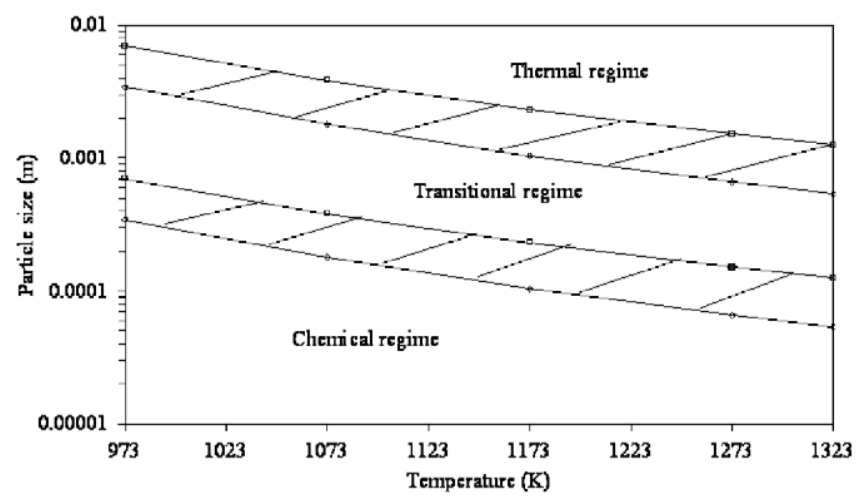

Fig. 1. Pyrolysis regimes versus temperature and particle size. temperatures were lower than $873 \mathrm{~K}$. It seems that the maximum particle sizes for chemical regime are of the same order of magnitude as those given by Peters. This is not the case with Simmons' results [23]. An extrapolation of Simmons' graph to higher temperatures leads to maximum particle sizes smaller than $1 \mu \mathrm{m}$ for chemical regime at about $1073 \mathrm{~K}$.

\section{Conclusions}

Gas phase can be represented by its five main species $\left(\mathrm{H}_{2}\right.$, $\mathrm{CO}, \mathrm{CO}_{2}, \mathrm{CH}_{4}$ and $\mathrm{H}_{2} \mathrm{O}$ ). This system is kinetically governed by two independent reactions. Under the operating conditions of interest, the reaction of steam reforming of $\mathrm{CH}_{4}$ is under chemical kinetic control. According to the analysis of some experimental results and to some authors, the water-gas shift reaction would be close to equilibrium at $1273 \mathrm{~K}$. This statement needs confirmation at $1073 \mathrm{~K}$.

A characteristic time analysis shows that

- The transformation can be seen as two successive steps: - Pyrolysis of biomass, whose time scale is smaller than $1 \mathrm{~s}$.

- Steam gasification of residue, whose time scale is far above $1 \mathrm{~min}$.

- Steam gasification of residue is controlled by chemical kinetics.

- Pyrolysis of biomass seems to occur in chemical regime for particles smaller than $100 \mu \mathrm{m}$ up to $1100 \mathrm{~K}$. In the other cases, the transformation seems to be controlled both by the heat transfer and the chemical kinetics. Gas-to-particle heat transfer occurs mainly by convection, but radiation may become significant for large particles. External heat transfer and internal conduction are on the same time scale.

\section{Acknowledgements}

We are grateful to G. Scacchi and P.-A. Glaude from the Département de Chimie Physique des Réactions of 
ENSIC-INPL (Nancy) for the kinetic simulations of the gas phase evolution made with the Chemkin software.

\section{References}

[1] Li XT, Grace JR, Lim CJ, Watkinson AP, Chen HP, Kim JR. Biomass gasification in a circulating fluidized bed. Biomass Bioenergy 2004;26:171-93.

[2] Boissonnet G, Seiler JM, Chataing T, Claudet G, Brothier M, Bertrand C. CEA activities on biomass gasification to produce synfuels. Pyrolysis and gasification of biomass and waste expert meeting, Strasbourg (France) 2002.

[3] Boissonnet G, Bayle J, Seiler JM, Chataing T, Rougé S, Bertrand C, et al. Comparison of several biomass steam gasification routes and technologies to produce hydrogen and synfuels. In: First European hydrogen energy conference, Grenoble, France; 2003.

[4] Boissonnet G, Seiler JM. Approche thermodynamique des transformations de la biomasse. Commissariat à l'Energie Atomique ReportR-6025, Grenoble, France; 2003.

[5] Boissonnet G, Seiler JM, Dupont C, Chataing T. Gazéification de la biomasse sèche: évaluation de procédés par une méthode thermodynamique. In: $9^{\circ}$ Congrès Français de Génie des Procédés, Saint Nazaire, France; 2003

[6] Hofbauer H, Rauch R, Foscolo P, Matera D. Hydrogen rich gas from biomass steam gasification. In: First world conference and exhibition on biomass for energy and industry, Sevilla, Spain; 2000.

[7] Rapagna S, Jand N, Kiennemann A, Foscolo PU. Steam-gasification of biomass in a fluidised-bed of olivine particles. Biomass Bioenergy 2000;19:187-97.

[8] Kersten SRA, Prins W, Van der Drift A, Van Swaaij WPM. Interpretation of biomass gasification by "quasi"-equilibrium models. In: Twelfth European conference on biomass for energy, industry and climate protection, Amsterdam, The Netherlands; 2002.

[9] Bamford CH, Crank J, Malan DH. The combustion of wood. Part I. Proc Cambridge Phil Soc 1946;42:166-82.

[10] Chan WCR, Kelbon M, Krieger BB. Modelling and experimental verification of physical and chemical processes during pyrolysis of a large biomass particle. Fuel 1985:64.

[11] Bradbury AGW, Sakai Y, Shafizadeh F. Kinetic model for pyrolysis of cellulose. J Appl Polym Sci 1979;29:3271-82.

[12] Koufopanos CA, Papayannakos N. Modelling of the pyrolysis of biomass particles. Studies on kinetics, thermal and heat transfer effects. Can J Chem Eng 1991;69:907-15.

[13] Raman P, Walawender WP, Fan LT, Chang CC. Mathematical model for the fluid-bed gasification of biomass materials. Application to feedlot manure. Ind Eng Chem Process Dev 1981;20:686-92.

[14] Golfier F, Mermoud F, Salvador S, Dirion JL, Van de Steene L. Modeling of char gasification at particle scale: how to select the best assumptions in the scope of fixed bed modelling. In: Second world conference on biomass for energy, industry and climate protection, Rome, Italy; 2004.

[15] Di Blasi C. Dynamic behaviour of stratified downdraft gasifiers. Chem Eng Sci 2000;55:2931-44.

[16] Matsui I, Kunii D, Furusawa T. Study of fluidized bed steam gasification of char by thermogravimetrically obtained kinetics. J Chem Eng Jpn 1985;18:105-13.

[17] Van de Steene L. Thermochimie de la combustion à basses températures de solides pulvérisés: application à un charbon, Mémoire de Thèse, INPT, Toulouse, France; 1999.

[18] Russel WB, Saville DA, Greene MI. A model for short residence time hydropyrolysis of single coal particles. AIChE J 1979;25:65-80.

[19] Damköhler G. Einflüsse der Strömung Diffusion und des Wärmeüberganges auf die Leistung von Reaktionsöffen. Z Elektrochem $1936 ; 42: 846$.

[20] Villermaux J, Antoine B. Pyrolyse éclair de solides divisés dans un réacteur continu: 1 . Un nouveau modèle de volatilisation thermique de particules solides. Revue Générale de Thermique 1980;227:85160.

[21] Pyle DL, Zaror CA. Heat transfer and kinetics in the low temperature pyrolysis of solids. Chem Eng Sci 1985;39:147-58.

[22] Bryden KM, Ragland KW, Rutland CJ. Modeling thermally thick pyrolysis of wood. Biomass Bioenergy 2002;22:41-53.

[23] Simmons GM, Gentry M. Particle size limitations due to heat transfer in determining pyrolysis kinetics of biomass. J Anal Appl Pyrolysis 1986;10:117-27.

[24] Wutti R, Petek J, Staudinger G. Transport limitations in pyrolysing coal particles. Fuel 1996;75:843-50.

[25] Peters B, Bruch C. Drying and pyrolysis of wood particles: experiments and simulation. J Anal Appl Pyrolysis 2003;70:1-18.

[26] Villermaux J. Génie de la réaction chimique: Conception et fonctionnement des réacteurs. Paris: éditions Tec \& Doc; 1993.

[27] Kee RJ, Rupley FM, Miller JA. Sandia Laboratories Report, SAND 89-8009B; 1993.

[28] Déglise X, Schlicklin Ph. Annexe 2 à la Proposition de participation au programme de recherche et développement valorisation chimique du bois. Personal communication, Université de Nancy, France; 1980.

[29] Zanzi R. Pyrolysis of biomass: Rapid Pyrolysis at High Temperature; Slow Pyrolysis for Active Carbon Preparation. PhD Thesis, Stockholm (Sweden): Royal Institute of Technology, 2001.

[30] Buekens AG, Schoeters JG. Modelling of biomass gasification. In: Overend RP, Milne TA, Mudge LK, editors. Fundamentals of thermochemical biomass conversion. London: Elsevier; 1982.

[31] Herguido J, Corella J, Gonzalez-Saiz J. Steam gasification of lignocellulosic residues in a fluidized bed at a small pilot scale. Effect of the type of feedstock. Ind Eng Chem Res 1992;31:1274-82.

[32] Perry RH, Green DW. Perry's chemical engineers' handbook. 7th ed. McGraw-Hill; 1997.

[33] Fuller EN, Schettler PD, Giddings JC. A new method for prediction of binary gas-phase diffusion coefficients. Ind Eng Chem 1966;58:18-27.

[34] Ranz WE, Marshall WR. Evaporation from drops. Chem Eng Prog 1952;48:141-6. p. 173-80.

[35] Gupta M, Yang J, Roy C. Specific heat and thermal conductivity of softwood bark and softwood char particles. Fuel 2003;82:919-27.

[36] Suuberg EM, Milosavljevic I, Lilly WD. NIST-GCR-94-645. US Department of Commerce; 1994.

[37] Forest Products Laboratory. Wood handbook-wood as an engineering material. Gen. Tech. Rep. FPL-GTR-113, US Department of Agriculture, Forest Service, Madison; 1999 [chapter 2-3].

[38] Grønli MG. A theoretical and experimental study of the thermal degradation of biomass. PhD Thesis, Faculty of Mechanical Engineering, Trondheim; 1996.

[39] Szekely J, Evans JW, Sohn HY. Gas-solid reactions. Paris: Ed.Academic Press; 1976.

[40] Wen CY. Noncatalytic heterogeneous solid fluid reaction models. Ind Eng Chem 1968;60:34-54.

[41] Patisson F, Galant François M, Ablitzer D. A non-isothermal, nonequimolar transient kinetic model for gas-solid reactions. Chem Eng Sci 1998;53:697-708.

[42] Schweich D. Génie de la réaction chimique. Paris: éditions Tec \& Doc; 2001.

[43] Brink DL, Massoudi MS. A flow reactor technique for the study of wood pyrolysis. I. Experimental. J Fire Flammab 1978;9:176-88.

[44] Biagini E, Fantozzi C, Tognotti L. Characterization of devolatilization of secondary fuels in different conditions. Combus Sci Technol 2004; 176:685-703.

[45] Nandi SP, Onischak M. Gasification of chars obtained from maple and jack pine woods. In: Overend RP, Milne TA, Mudge LK, editors. Fundamentals of thermochemical biomass conversion. England: Elsevier Applied Science Publishers; 1982.

[46] Kojima T, Assavadakorn P, Furusawa T. Measurement and evaluation of gasification kinetics of sawdust char with steam in an experimental fluidized bed. Fuel Process Technol 1993;36:201-7. 